\title{
Difference In The Lower Blood Pressure Of Primary Hypertension Patients Participating In Prolanis and Non Prolanis In The Cipayung District Health Center
}

\author{
Alviani', Fajar Susanti', Erlin Ifadah ${ }^{2}$ \\ University Respati Indonesia \\ alvianilatifah@gmail.com
}

\begin{abstract}
Changes in human development at this time greatly affect lifestyles it is a cause of an increase in noncommunicable diseases (PTM) one of which is hypertension. Hypertension control has been pursued by the government by implementing a chronic disease prevention program (PROLANIS) through collaboration with BPJS. This study aims to determine the difference in blood pressure reduction in primary hypertension patients who follow prolanis and non prolanis in the Cipayung District Health Center. Pre-experimental research design with static group comparison research. The study population was primary hypertension patients who followed prolanis and non prolanis in the Cipayung District Health Center. Samples were taken by purposive sampling and found 40 people. The collected data is tested statistically by T-test. The results of the study of primary hypertension patients who follow Prolanis have better blood pressure. Statistical test results showed there were differences in blood pressure reduction in primary hypertension patients who followed prolanis and non prolanis $(\mathrm{p}=0,000, \mathrm{p}<0.05)$. Nurses provide education to primary hypertension patients who have not yet joined the program to participate in the PROLANIS program.
\end{abstract}

Keyword: Prolanis, Blood Pressure, Hypertension

\section{Background}

Changes in human development at this time greatly affect lifestyles due to urbanization, modernization, and globalization it is one of the causes of an increase in non-communicable diseases (PTM). Lifestyle is the most important factor that greatly influences people's lives. Unhealthy lifestyles such as fatty foods, lack of physical activity, stress, and smoking can cause many diseases such as coronary heart disease, stroke, and diabetes mellitus (Puspitorini, 2009). Based on the results of the study of Suoth (2014) the relationship of lifestyle with the incidence of hypertension in the health center in the subdistrict of Kalawat, North Minahasa regency, the results of the study that lifestyle greatly influences the occurrence of hypertension.

Hypertension or high blood pressure is an increase in systolic blood pressure of more than $140 \mathrm{mmHg}$ and diastolic blood pressure of more than $90 \mathrm{mmHg}$ at two 
measurements with an interval of five minutes in a state of sufficient rest / calm (Infodatin, 2018). Hypertension is referred to as the silent killer because it is often without complaints, so the patient does not know he has hypertension and only becomes known after complications occur. Increased blood pressure that lasts for a long time (persistent) can cause damage to the kidneys (kidney failure), heart (coronary heart disease) and brain (causing strokes) if not detected early and receive adequate treatment.
Hypertension is one of the chronic diseases and is the most common cause of cardiovascular disease which is a major problem in developed and developing countries. Cardiovascular disease is also the number one cause of death in the world every year. WHO data shows that around 1.13 billionpeople in the world suffer from hypertension, but only $36.8 \%$ of them take hypertension medication. The number of people with hypertension in the world continues to increase every year, it 
is estimated that in 2025 there will be 1.5 billion people affected by hypertension, it is also estimated that every year there are

9.4 million people die from hypertension and complications. (RI Ministry of Health, 2018).

The prevalence of data in Southeast Asia, in 2008, cases of hypertension covered almost one third of the adult population and an estimated 1.5 million people in Southeast Asia died of hypertension (Ministry of Health, Republic of Indonesia, 2018). The prevalence of hypertension data in Indonesia that can be measured by age $\geq 18$ years is $34.1 \%$ but only $8.8 \%$ of those diagnosed by health workers or taking anti-hypertension medication. The data shows that there is an increase in the number of hypertension prevalence through measurements at the age of yaitu 18 which is $8.3 \%$ from the results of riskesdas in 2013. In DKI itself the prevalence of hypertension that can be through measurements at the age of $\geq 18$ years by $33.43 \%$ while diagnosed with by health workers or taking anti-hypertensive drugs only $10.17 \%$ (RISKESDAS, 2018).

Control of infectious diseases (PTM) such as hypertension has been sought by the government, not only by curative control but also preventive prevention. Countermeasures are focused on the First Level Health Facilities (Puskesmas) as the frontline in providing services to the community can carry out chronic disease prevention programs (PROLANIS), through collaboration with BPJS to provide guidance for patients withchronic diseases (type 2 diabetes mellitus and hypertension) (BPJS, 2010).

Prolanis is a health service system and a proactive approach implemented in an integrated manner involving participants, health facilities and BPJS Health in the context of health care for BPJS Health participants who suffer from chronic diseases to achieve optimal quality of life with the cost of effective and efficient health services (BPJS , 2010).

Based on the profile of the Cipayung District Health Center the prevalence of hypertension in 2018 in the age category $\geq$ 18 years from 24,631 people totaling 7,277 people received blood pressure testing services and around 3,627 people who affected by hypertension. The phenomenon that occurs in the Cipayung District Health Center related to the incidence of hypertension is that a lot of people who come for treatment with complaints of dizziness and pain in the neck, after reviewing and measuring vital signs it turns out that the blood pressure of residents who seek treatment reaches 200/100 mmhg. Another event that is when a patient comes for treatment with complaints of nosebleeds when waking up, after assessment and measurement of vital signs it turns out that his blood pressure reaches 240/120 mmhg, the phenomenon or event that deserves attention so that complications from hypertension do not occur.

The high incidence of hypertension in the scope of the Cipayung sub-district health center and seeing the phenomena or events in patients diagnosed with primary hypertension make the writer want to know the evaluation of the success of one of the hypertension control activities namely the Prolanis program. One evaluation that can be measured from these activities is a decrease in blood pressure in hypertensive patients who follow Prolanis and compare with those who do not follow Prolanis.

\subsection{Problem Formulation}

From the description of the back floor. then this research problem can be formulated as follows:

"What is the difference in the reduction in blood pressure of primary hypertension patients who follow Prolanis and non- 
prolanis in the Cipayung District Health Center"

\subsection{Research Objectives}

\subsubsection{General Purpose}

Knowing the difference in decreasing blood pressure in primary hypertension patients who follow Prolanis and primary hypertension patients who do not follow Prolanis in the Cipayung District Health Center

\subsubsection{Special Purpose}

a. It is known that the frequency of blood pressure distribution of primary hypertension patients who follow prolanis at the Cipayung District Health Center

b. It is known that the frequency of blood pressure distribution of primary hypertension patients who do not follow the prolanis in Cipayung District Health Center.

c. It is known the difference in blood pressure of primary hypertensive patients who follow prolanis and do not follow prolanis.

\section{RESEARCH METHODOLOGY}

\subsection{Research Design}

researchers used a quantitative approach with a pre-experimental design, the type of research used is the static group comparison. This is intended to determine the difference in blood pressure reduction in primary hypertension patients who follow prolanis and non prolanis in the Cipayung District Health Center.

\subsection{Research Place and Time}

This research was conducted at the puskesmas sub-district of Cipayung. The process of making proposals to the results of the research carried out in the months of August 2019 - February 2020 and data collection carried out in December 2019 January 2020.

\subsection{Population and Sample}

The population in this study were patients at the Cipayung sub-district health center with a diagnosis of pure hypertension who participated in prolanis as many as 92 people and who did not attend as many as 128 people.

Sampling in this study with purposive sampling technique, in determining the size of the sample is done using the Federer formula. The minimum number of samples that can be taken is 16 samples. Researchers added a sample of $10 \%$, a total sample of 40 patients with a division of 2 groups of samples that were observed for 2 months, 20 primary hypertension patients who participated in prolanis and 20 primary hypertension patients who did not follow prolanis

\section{RESEARCH RESULT}

Univariate Analysis Results

Table 5.1 Frequency distribution of blood pressure of primary hypertension patients who follow prolanis in the Cipayung District Health Center by category $(n=20)$

\begin{tabular}{|c|c|c|}
\hline $\begin{array}{l}\text { Measurement } \\
\text { category } 1\end{array}$ & Frequencies & Percentage \\
\hline $\begin{array}{l}\text { Pre Hypertension } \\
(120-139 / 80-89)\end{array}$ & 13 & $65 \%$ \\
\hline $\begin{array}{l}\text { Hypertension } \\
\text { Grade } 1 \\
(140-159 / 90-99)\end{array}$ & 6 & $30 \%$ \\
\hline $\begin{array}{l}\text { Hipertensi Grade } 2 \\
(\geq 160 / \geq 100)\end{array}$ & 1 & $5 \%$ \\
\hline Total & 20 & $100 \%$ \\
\hline
\end{tabular}




\begin{tabular}{|c|c|c|}
\hline $\begin{array}{l}\text { Measurement } \\
\text { category } 2\end{array}$ & Frequencies & Percentage \\
\hline $\begin{array}{l}\text { Normal } \\
(<120 /<80)\end{array}$ & 9 & $45 \%$ \\
\hline $\begin{array}{c}\text { Pre Hypertension } \\
(120-139 / 80-89) \\
\end{array}$ & 7 & $35 \%$ \\
\hline $\begin{array}{l}\text { Hypertension Grade } 1 \\
(140-159 / 90-99)\end{array}$ & 4 & $20 \%$ \\
\hline Total & 20 & $100 \%$ \\
\hline
\end{tabular}

blood pressure measurement results in primary hypertension patients who follow prolanis at the Cipayung District Health Center, from the total of 20 respondents obtained data on the first measurement of 13 patients $(65 \%)$ pre hypertension category, 6 patients $(30 \%)$ grade 1 hypertension category, 1 patient $(5 \%)$ grade 2 hypertension. In the second measurement of blood pressure in systole and diastole with results in the normal category of 9 patients (45\%), in the category of hypertension being 7 patients (35\%), grade 1 hypertension category of 4 patients $(20 \%)$.

Table 5.2 Distribution of blood pressure frequency of primary hypertension patients who do not follow prolanis in the Cipayung District Health Center by category $(n=$

\begin{tabular}{|c|c|c|}
\hline $\begin{array}{l}\text { Measurement } \\
\text { category } 1\end{array}$ & Frequencies & Percentage \\
\hline $\begin{array}{l}\text { Pre Hypertension } \\
(120-139 / 80-89)\end{array}$ & 9 & $45 \%$ \\
\hline $\begin{array}{l}\text { Hypertension } \\
\text { Grade } 1 \\
(140-159 / 90-99)\end{array}$ & 9 & $45 \%$ \\
\hline $\begin{array}{l}\text { Hipertensi Grade } 2 \\
(\geq 160 / \geq 100)\end{array}$ & 2 & $10 \%$ \\
\hline Total & 20 & 100 \\
\hline
\end{tabular}

Table 5.2 based on the measurement of blood pressure in primary hypertension patients who do not follow prolanis in the Cipayung District Health Center, from the total of 20 respondents obtained data on the first measurement of both systole and diastole, 9 patients $(45 \%)$ in the category of pre hypertension, 9 patients $(45 \%)$

categories grade 1 hypertension, 2 patients (10\%) grade 2 hypertension. In systole and diastole blood pressure measurements, the results in the pre hypertension category were 3 patients (15\%), grade 1 hypertension category as many as 10 patients $(50 \%)$, and the hypertension category grade 2 as many as 7 patients $(35 \%)$.

\section{Bivariate Analysis Results}

Table 5.6 Results of bivariate analysis of differences in blood pressure reduction in primary hypertensive patients who follow prolanis and non prolanis $(n=40)$

\begin{tabular}{|c|c|c|}
\hline $\begin{array}{l}\text { Measurement } \\
\text { category } 2\end{array}$ & Frequencies & Percentage \\
\hline $\begin{array}{l}\text { Pre Hypertension } \\
(120-139 / 80-89)\end{array}$ & 3 & $15 \%$ \\
\hline $\begin{array}{l}\text { Hypertension } \\
\text { Grade } 1 \\
(140-159 / 90-99)\end{array}$ & 10 & $50 \%$ \\
\hline $\begin{array}{l}\text { Hypertension } \\
\text { Grade } 2 \\
(\geq 160 / \geq 100)\end{array}$ & 7 & $35 \%$ \\
\hline Total & 20 & 100 \\
\hline
\end{tabular}

http://ejournal.urindo.ac.id/index.php/JournalOfAgeingAndFamily/index 
Journal Of Ageing And Family (JOAF)

Edition 1, No 1, October 2021

\begin{tabular}{|c|c|c|c|}
\hline Variable & $\begin{array}{l}\text { Blood } \\
\text { Pressure }\end{array}$ & Mean & $\begin{array}{l}\text { Standart } \\
\text { Deviation }\end{array}$ \\
\hline Prolanis & Sistole 1 & 140,15 & 10,816 \\
\hline \multirow{7}{*}{$\begin{array}{l}\text { Non } \\
\text { Prolanis }\end{array}$} & Sistole 2 & 126,55 & 9,939 \\
\hline & Diastole 1 & 87,40 & $\underline{5,826}$ \\
\hline & Diastole 2 & $\underline{81,15}$ & $\underline{5,143}$ \\
\hline & Sistole 1 & 142,05 & 12,107 \\
\hline & Sistole 2 & 152,80 & $\underline{12,412}$ \\
\hline & Diastole 1 & 91,15 & 6,209 \\
\hline & Diastole 2 & 94,40 & 6,219 \\
\hline
\end{tabular}




\begin{tabular}{lllll}
\hline Variable & $\begin{array}{l}\text { Blood } \\
\text { Pressure }\end{array}$ & $\begin{array}{l}\text { Standart } \\
\text { Error }\end{array}$ & N & $\begin{array}{l}\text { p } \\
\text { Value }\end{array}$ \\
\hline Prolanis & Sistole 1 & 2,418 & 20 & 0,0000 \\
\hline & Sistole 2 & 2,222 & 20 & \\
\hline & Diastole 1 & 1,303 & 20 & \\
\hline Non & Diastole 2 & 1,150 & 20 & \\
Prolanis & Sistole 1 & 2,707 & 20 & \\
\hline & Sistole 2 & 2,775 & 20 & \\
\hline & Diastole 1 & 1,388 & 20 & \\
\hline & Diastole 2 & 1,391 & 20 & \\
\hline
\end{tabular}

Statistical test results, obtained data value of $p=0,000$. Because the value of $p \leq \alpha$, it can be concluded that there are differences in blood pressure of primary hypertension patients who follow prolanis and non prolanis. Based on the difference test above, it can be concluded that there is a significant difference in blood pressure in primary hypertension patients who follow prolanis and non prolanis.

\section{DISCUSSION}

\subsection{Univariate Discussion}

\subsubsection{Blood pressure of primary hypertensive patients who follow Prolanis}

Based on the results of the first and second measurements in primary hypertension patients who follow prolanis is a decrease in blood pressure towards more normal seen in the decrease in the frequency of blood pressure in the category of pre hypertension, grade 1 hypertension, grade 2 hypertension and an increase in frequency in the normal category.
According to PERKI (2015), pharmacological management of hypertension with antihypertensive and non-pharmacological drugs such as reducing salt consumption, losing weight, reducing salt consumption, stopping smoking and reducing alcohol, these activities are in accordance with activities that have been running on prolanis. Application of hypertension management in non-pharmacological when prolanis 
such as physical activity carried out with exercise can affect blood pressure, this is in line with research according to Carmen (2017) Physical activity is able to show a reduction in the risk of death by $29 \%$ to $67 \%$ in patients with high physical activity, and as many as $12 \%$ to $35 \%$ in patients with moderate physical activity, this reflects that there is a relationship between physical activity and decreased risk of death in hypertensive patients

Decreased blood pressure is also influenced by educational activities. in hypertension patient prolanis activities will be given educational activities. According to the Ministry of Health (2017), Education is also one of the control of non-communicable diseases (PTM) such as hypertension. hypertension control is not only curative but also preventive and promotive, in line with government programs in Indonesia by increasing health promotion through IEC (communication, information and education) increasing prevention and control of community-based hypertension with Self Awareness through pressure measurement routine blood pressure and strengthening health services especially hypertension
Decrease in blood pressure of prolanis patients is also influenced by adherence to take medication not only with physical activity, and education alone, but adherence to taking medication to support a decrease in blood pressure. based on research noorhidayah (2016) about adherence to taking antihypertensive drugs to blood pressure in hypertension patients in the village of Salamrejo, the results showed that there is a relationship between adherence to taking antihypertensive drugs to blood pressure of hypertensive patients both systolic and diastolic blood pressure.

Prolanis ativities include physical activity activities with gymnastics, education by health workers, health 
consultations, while pharmacologically by administering medication for one month and monitoring taking medication to evaluate patient compliance for taking medication if routinely done will have a positive impact on patients with primary hypertension. like changes in blood pressure towards normal. Prolanis activities can improve the optimal quality of life of primary hypertensive patients so as not to cause further complications such as stroke, cardiovascular disease and even death.

\subsubsection{Blood pressure of primary hypertension patients who do not follow Prolanis}

Based on the results of the first and second measurements in primary hypertension patients who follow prolanis there is an increase in blood pressure towards the abnormal seen in the category 1 hypertension category, and the category 2 hypertension category

The increase in blood pressure that occurs is caused by many factors, according to the theory according to Manuntung (2018) Risk factors that aggravate the occurrence of hypertension are age, sex, family history, salt consumption, smoking, physical activity and stress.

Risk factors for hypertension that can be changed and cannot be changed, factors that cannot be changed include age, genetics, gender while factors that can be changed are smoking, low-fiber diet, dyslipidemia, excessive salt consumption, lack of physical activity, stress, excess weight, and alcohol consumption(P2PTM KEMENKES RI, 2018)

These theories are reinforced by Sari's research (2016) Factors that Influence Hypertension in Kudu Sub-District, Semarang Regency, explain the factors that influence Hypertension including environmental factors such as smoking, fried and fried cooking culture. genetic factors such as the presence of family members who experience hypertension. Behavioral factors such as smoking, never or not regularly taking anti-hypertensive drugs, consuming coffee, consuming fatty foods, consuming coconut milk, lack of exercise habits. Health factors such as early detection of health facilities are lacking and there are still many residents who do not participate in PROLANIS.

These factors can be related to prolanis activities that have been running that an increase in blood pressure occurs in hypertensive patients who do not follow Prolanis can be caused by smoking, never or not regularly taking anti-hypertensive drugs, the habit of consuming coffee, consuming fatty foods, consuming fatty foods, lack of sports habits, and there are still many people who do not follow PROLANIS

Based on the results of research conducted by hypertensive patients who do not follow Prolanis do not have routine activities that are programmed, in other words hypertension patients who do not follow Prolanis do not all carry out activities that can help lower blood pressure such as physical activity, education and monitoring compliance with taking medication. Primary hypertension patients who do not take part in prolanis will control poly PTM (NonCommunicable Disease), primary hypertension patients who control poly will be given education by health workers on duty while in control, and drug administration will be given for stock for a maximum of 14 days (2 weeks) ).

Based on the results of interviews conducted during the research process the limited drug administration is also a factor that affects patients not routinely to take medication, because when the drug stock is exhausted some patients do not directly control the poly PTM for blood pressure evaluation, there are many reasons underlying why patients do not directly control like the patient said that they did 
not have time to work, did not have time because no one accompanied them to the puskesmas, and some did forget to control. This can exacerbate the risk of an increase in blood pressure, it is recommended for patients with pure hypertension who have not participated in the prolanis program so that in the future they can take part in the program so that improving the quality of health can be achieved

\subsection{Bivariate Discussion}

Based on the results of the above study it was found that there were differences in the decrease in blood pressure of hypertensive patients who followed prolanis and non prolanis

The difference in blood pressure reduction in hypertensive patients is influenced by prolanis activities which include medical consultations, prolanis participant education, SMS Gateway Reminder, home visits, club activities (gymnastics) and health status monitoring that can help reduce and stabilize blood pressure in primary hypertension patients (BPJS, 2010).

Prolanis activities documented such as club activities (gymnastics), prolanist education, medical consultations, health status monitoring, medication adherence are filled every day and evaluated every month by health workers when prolanist activities are carried out

Prolanis physical activity can help stabilize blood pressure according to Eka's research (2019) about the correlation of stress and physical activity with blood pressure in patients with essential hypertension. It can be concluded that there is a significant relationship between physical activity and blood pressure in patients with essential hypertension.

Decreased blood pressure in primary hypertensive patients who follow prolanis is not only influenced by activity but because of educational activities and medication adherence. Education is one form of intervention that can be done to be able to change knowledge and attitudes so that health status can increase. this was proven in the Septiani study (2017). The Effects of Nutrition Education on Knowledge and Eating Habits of Participants in Type 2 Diabetes Mellitus Management Program in Prolactis inElok Milling Village, East Jakarta, the results of the study showed the influence of nutrition education.

Increased education also has an effect on improving one's health status by increasing the ability of the community to make health efforts themselves. Health efforts that can be done by hypertensive patients, namely adherence to taking hypertension medication to help curative blood pressure improvement. Adherence to take medication can be influenced by knowledge of the illness and can affect the treatment process, especially in taking medication and provide optimal outcomes. Low understanding of hypertension will stop treatment when you feel your blood pressure returns to normal, this will be very dangerous in chronic conditions. based on Setiawan's research (2017) The Relationship of Compliance with Taking Drugs on the Quality of Life of Hypertensive Patien

the results of the study there is a significant relationship between the level of adherence to the quality of life of hypertensive patients Compliance is one of the factors that can affect the quality of life even though it is not a major factor

The quality of life of hypertensive patients is strongly influenced by the style, the patient's experience of his lifestyle is also related to the length of illness. When the experience is good it means that the patient can make his health better so that the experience can increase motivation to make a healthy lifestyle. However, if the previous experience is not good, then the 
experience will reduce his motivation to perform self-care so that health can occur.

Lifestyle is influenced by perceptual and cognitive factors, that is, when patients know for certain about a healthy lifestyle and understand how to deal with problems that arise, the patient knows when to behave well and badly so that this increases a healthy lifestyle

A healthy lifestyle includes nonpharmacological management of hypertension. The prolanis program that has been running at the Cipayung subdistrict health center provides positive results for patients with primary hypertension, in addition to their blood pressure being far more controlled, these activities are also able to discipline patients in the treatment of hypertension.
Health workers also need to pay attention to patient compliance factors because the longer a person suffers from hypertension, the lower the level of obedience. This is also related to the amount of drugs taken, in general patients who have been suffering from hypertension for a long time but have not yet recovered, so the doctor who handles these patients will usually add to the type of drug or will increase the dose slightly. As a result, these patients tend not to comply with treatment

The role of nurses is very needed in the process of managing hypertension, in addition to providing motivation to patients also providing education that treatment hypertensio can help stabilize blood pressure so that it can heal.

\section{CONCLUSIONS}

\subsection{Conclusions}

Based on the results of research on the differences in blood pressure of primary hypertension patients who follow prolanis and non prolanis, it can be concluded that 
the systolic and diastolic blood pressure of primary hypertensive patients who follow the prolanis program is better than those who do not follow the program. There was a significant difference in the blood pressure of hypertensive patients who followed prolanis and did not participate in the prolanis program at the Cipayung District Health Center. It was found that the blood pressure of primary hypertension patients who took 0,000 or $\mathrm{p}$

$<\alpha(\alpha=0.05)$ then $\mathrm{H} 0$ was rejected, which means there is a difference between blood pressure between primary hypertensive patients who follow prolanis and do not follow prolanis.

\subsection{Suggestions}

\section{For Puskesmas}

The results of the study are suggested to be used as a basis so that in the future all health workers, especially nurses at the Cipayung District Health Center can provide education to patients with primary hypertension to participate in the prolanis program as one of the primary hypertension treatment programs in pharmacology and non pharmacology so as to improve the status of health status.

\section{For nurses}

The results of this study are recommended for nurses to attend training related to the prolanist program, especially for new nurses or for nurses who have never been exposed to the prolanist program.

\section{For educational institutions}

The results of the study are suggested to be used as reference material for introducing prolanis programs when giving lecture material, so that when students already know the program before going to the field to practice

\section{For further researchers}

The results of this study are suggested to be used as a reference for further research by using different variables in order to 
conduct more in-depth research with observations to patients every day related to evaluating the response to the prolanis program.

\section{BIBLIOGRAPHY}

Badan Penyelenggara Jaminan Sosial. (2010). Panduan Praktis PROLANIS (Program Penanggulangan Penyakit Kronis).Jakarta: BPJS kesehatan

Carmen, K. (2017). Physical Activity Reduces The Risk Of Death In Patients With Hipertension, Majalah Internasional Duarazy. 14(1).

Eka. (2019). Korelasi Stres dan Aktivitas Fisik dengan Tekanan Darah pada Penderita Hipertensi Essensial.Jurnal Ilmiah Universitas Batanghari Jambi, Vol. 19, No. 1, 147-151

Kementerian Kesehatan. (2019). Laporan Nasional RISKESDAS 2018. Jakarta. Badan Penelitian dan Pengembangan Kesehatan
Manuntung, (2018). Terapi Perilaku Kognitif Pada Pasien Hipertensi.Malang. Wineka Medika.

Murti. (2017). Pengaruh prolanis terhadap Penurunan Tekanan Darah Pasin Hipertensi DiPuskesmas Pandak II Kabupaten Bantul, Universitas Gadjah Mada

Perhimpunan Dokter Spesialis Kardiovaskular Indonesia. (2015). Pedoman Tatalaksana Hipertensi Pada Penyakit Kardiovaskular, Edisi Pertama

Septiani, (2019). Pengaruh Edukasi Gizi Terhadap Pengetahuan Dan 
Journal Of Ageing And Family (JOAF)

Edition 1, No 1, October 2021

Kebiasaan Makan Pada Peserta Program Pengelolaan Penyakit

Kronis (Prolanis) Diabetes Mellitus Tipe

2 Di Kelurahan Penggilingan I Elok Jakarta Timur. Jurnal

Kesehatan Masyarakat, Vol.5 No.2.

Noorhidayah, (2016). Hubungan Kepatuhan Minum Obat Antihipertensi Terhadap Tekanan Darah Pasien Hipertensi Di Desa Salamrejo.

Sari, (2016). Faktor- Faktor Yang Mempengaruhi Hipertensi. Jurnal Ilmiah Permas: Jurnal Ilmiah STIKES Kendal Volume 6 No 1 ,

Hal $1-10$
Setiawan, (2019). Hubungan Kepatuhan Minum Obat Terhadap Kualitas Hidup Pasien Hipertensi. Jurnal Darul Azhar Vol 8, No.1 , Hal 15 $: 18$

Suoth. (2014). Hubungan Gaya Hidup Dengan Kejadian Hipertensi Di Puskesmas Kolongan Kecamatan Kalawat Kabupaten Minahasa Utara. ejournal keperawatan (eKp), Vol.2,No. 1 